\title{
Removal of Methylene Blue, Rhodamine $B$ and Ammonium Ion from Aqueous Solution by Adsorption onto Sintering Porous Materials Prepared from Coconut Husk Waste
}

\author{
Ahmed H. A. Dabwan ${ }^{*}$, Nakane Yuki², Nur Amni Mohd Asri ${ }^{1}$, Hideyuki Katsumata ${ }^{2,3}$, \\ Tohru Suzuki ${ }^{3,4}$, Satoshi Kaneco ${ }^{2,3,4}$ \\ ${ }^{1}$ Faculty of Chemical Engineering Technology, Tati University College, Terengganu, Malaysia \\ ${ }^{2}$ Department of Chemistry for Materials, Graduate School of Engineering, Mie University, Mie, Japan \\ ${ }^{3}$ Mie Global Environment Center for Education \& Research, Mie University, Mie, Japan \\ ${ }^{4}$ Research Center of Process for Environmental Load Reduction, Mie University, Mie, Japan \\ Email: *ahmedmie2000@gmail.com
}

Received 14 January 2015; accepted 30 January 2015; published 2 February 2015

Copyright (C) 2015 by authors and Scientific Research Publishing Inc.

This work is licensed under the Creative Commons Attribution International License (CC BY). http://creativecommons.org/licenses/by/4.0/

(c) (i) Open Access

\begin{abstract}
The present work was done in order to develop and find out suitable conversion methods for coconut husk wastes into value-added products. It is well-known that coconuts husk waste is hydrophobic therefore ethanol with different doses was used as a surfactant to enhance the removal efficiency. Treated samples at different adsorbent amounts, sintering temperatures \& sintering time, stirring time, pH, and solution temperatures for color removal of Methylene Blue (MB) \& Rhodamine $B(\mathrm{RhB})$ and ammonium concentration were evaluated by using UV-Visible Spectroscopy. At $300^{\circ} \mathrm{C}$, results showed complete removal for $\mathrm{MB}$ and more than $\mathbf{7 5 \%}$ for $\mathrm{RhB}$, whereas removal of ammonium ion reached around $52 \%$ when sintering product from husk waste was used. Further investigation was carried out for ammonium ion to understand the desorption kinetic behaviors and isotherm models. Kinetics indicated that desorption of ammonium ion followed pseudo-first order equation. Adsorption thermodynamic parameters such as $\Delta G, \Delta H$, and $\Delta S$ followed Van't Hoff plot for adsorption and found to be negative which indicated that the adsorption process for ammonium onto coconut husk was physical, spontaneous and exothermic.
\end{abstract}

"Corresponding author.

How to cite this paper: Dabwan, A.H.A., et al. (2015) Removal of Methylene Blue, Rhodamine B and Ammonium lon from Aqueous Solution by Adsorption onto Sintering Porous Materials Prepared from Coconut Husk Waste. Open Journal of Inorganic Non-Metallic Materials, 5, 21-30. http://dx.doi.org/10.4236/ojinm.2015.52003 


\section{Keywords}

\section{Coconut Husk, Sintering Temperature, Methylene Blue, Rhodamine B, Ammonium Ions, Adsorption, Kinetics}

\section{Introduction}

In a typical aquatic environment, organic dyes such as Methylene Blue (MB) and Rhodamine B (RhB) as well as ammonium ions are present as soluble molecules and ions and are too difficult to remove from aqueous media resulting damage to the receiving water bodies; moreover, some dyes are toxic and suspected carcinogens [1]-[6]. Existing techniques used for treatment are oxidation and precipitation, coagulation and co-precipitation, nano \& micro filtration, reverse osmosis and electro-dialysis, adsorption, ion exchange, foam flotation, solvent extraction, bioremediation, and photo-catalytic degradation [7]-[20]. These approaches have been adapted for the removal of $\mathrm{MB}$, RhB dye and ammonium ion having their respective advantages and certain disadvantages that include the generation of toxic waste, low removal efficiency in addition to the high cost.

Adsorption is one of the most effective methods so far used for treating different wastes. MB, RhB dyes, ammonium ions and heavy metals could be removed through this technique by preparing efficient desorbent materials such as mineral oxides and biological materials. The use of polymeric resins, activated carbon, activated alumina, iron coated sand, hydrous ferric oxide, and natural ores has generated much interest, and novel metal modified adsorbents have demonstrated superior performance [21]-[34].

Although adsorbent is highly effective, the running costs are also high. Therefore, locally available and abundant material should be used as a source for producing cost-effective adsorbent. In this regard, however, Malaysia has an abundant supply of coconut husk due to being one of the leading coconut milk producers. The coconut husk generated creates a serious disposing problem. The coconut husk have been used as the raw material due to the availability and inexpensive material with high carbon and low inorganic content for adsorbent production and several researchers have concluded that a good quality product can be obtained. Moreover, adsorbents prepared by coconut wastes have the character to be highly efficiency adsorbent materials for wastes exist in diluted solution. Adsorbents are prepared physically by burning the coconut husks wastes at high temperature. As a result, sintered adsorbent with high specific surface areas could lead to better performance due to their microporous structure and high adsorption ability for organic compounds and heavy metal ions. In this regard, other sintering porous material made from sea bottom sediments prepared at $\left(400^{\circ} \mathrm{C}\right)$ was applied and found to be effective adsorbent for removing heavy metals [33].

Recent works with coconut shell activated carbon have been reported for the treatment of ammonium ion. However, treated method involved two main steps. The first step was pre-carbonization (at $400^{\circ} \mathrm{C}$ ) and the second step was chemical activation (by agitation with $85 \% \mathrm{H}_{3} \mathrm{PO}_{4}$ aqueous solution) [35].

In this work, a simple and cheap method for using coconut sintering husk wastes at different temperatures $\left(100^{\circ} \mathrm{C}\right.$ to $\left.400^{\circ} \mathrm{C}\right)$ was evaluated. Husk wastes are available in very large quantities in many established industries in Malaysia, which are being dumped after getting milk from the coconuts. Sintering products are used as an effective adsorbent for the removal of $\mathrm{RhB}, \mathrm{MB}$, and ammonium ion. Chemical formulas of the contaminants are shown in Figure 1.

\section{Experimental}

\subsection{Raw Materials and Drying Process}

Raw material (coconut husks) was collected from Kemaman Area, Terengganu, Malaysia. After collection the

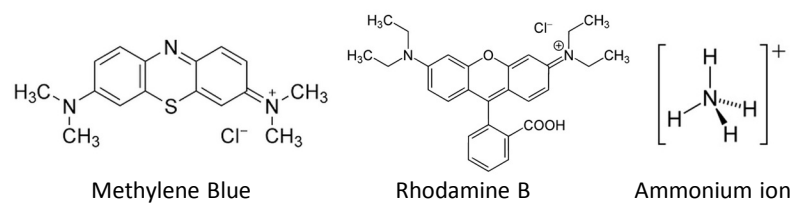

Figure 1. Chemical formulas of RhB, MB and ammonium ion. 
husks thoroughly washed at least three times with deionized water, initial drying process was carried out under natural drying. Further drying was carried out in oven at $105^{\circ} \mathrm{C}$ to remove moisture. After complete drying the samples were ground and sieved to obtain a particle size between 53 - $74 \mu \mathrm{m}$.

\subsection{Preparation of Sintering Adsorbent}

Sintering products from cocoanuts husk wastes were prepared by using an electric oven (Kyoto Thermo System Co. Ltd. KBF828N, Nara, Japan). Different temperatures with different sintering time were selected to examine the removal efficiency.

\subsection{Adsorption Experiments}

All experiments were carried out with $100 \mathrm{ml}$ vial glass as a batch reactor. Cocoanuts husks known as hydrophobic. In order to enhance the removal efficiency, ethanol was added as a surfactant (0.1 - $2 \mathrm{ml})$. Stock solutions for both $\mathrm{MB}$ and $\mathrm{RhB}$ were prepared by dissolving high purity fine powder of $\mathrm{Mb}$ and $\mathrm{RhB}$ so that 2.5 $\mu \mathrm{g} / \mathrm{ml}$ was obtained as a working solution. Ammonium ions were prepared by dissolving anhydrous ammonium chloride so that stock solution of $100 \mu \mathrm{g} / \mathrm{ml}$ was obtained. Working solution was prepared by diluting the stock solution with deionized water as required. Adsorption experiment was carried out by weighing the required amount of the sintering products $(10-300 \mathrm{mg})$ prepared at different temperatures $\left(100^{\circ} \mathrm{C}-400^{\circ} \mathrm{C}\right)$ with different sintering time (30 - $180 \mathrm{~min}$ ). Stirring time was adjusted to be between 5 \& 75 min. Desired pH (4.2 - 9.7) was adjusted by using $\mathrm{NaOH}$, and/or $\mathrm{HCl}$ solutions. At different intervals samples were collected after treatment, filtered with $0.45 \mu \mathrm{m}$ Advantec membrane filter then analyzed.

\subsection{Characterization \& Instrumentation}

The BM, RhB and ammonium ion concentrations in the aqua forms were obtained by the determination of the absorbance at the characteristics wavelength using a double beam UV/Visible spectrophotometer. Standard solutions were prepared to determine the proper wavelengths for the BM, RhB and ammonium. The wavelengths corresponding to the maximum absorbance observed were 665, 540 and $644 \mathrm{~nm}$ for $\mathrm{MB}, \mathrm{RhB}$ and ammonium ion respectively. The XRD of carbon powder was prepared by grinding the required sintering product amount in an agate at $\left(300^{\circ} \mathrm{C}\right)$ for $30 \mathrm{~min}$. Crystallinity was not observed in the carbon powder (result not shown). Morpholgy study was carried out by Scanning Electron Microscopy (SEM); S-4000, Hitachi, Japan.

\section{Results \& Discussion}

\subsection{Optimal Condition for BM, RhB \& Ammonium Ion Removal}

Experiments were carried out with sintering products treated at different temperatures as adsorbent material. Coconut husk waste (adsorbent) is known as strong hydrophobic. To overcome this problem, ethanol was added as a surfactant. Series of experiments were carried out to investigate the effect of surfactant for the removal efficiency of $\mathrm{MB}, \mathrm{RhB}$ and ammonium ions. Different adsorbent dosages $(10-300 \mathrm{mg})$ were used with different amount of ethanol $(0.1-2 \mathrm{ml})$ in order to evaluate the removal efficiency of $2.5 \mu \mathrm{g} / \mathrm{ml} \mathrm{MB} \& \mathrm{RhB}$ initial concentration from both dyes, and $1 \mu \mathrm{g} / \mathrm{ml}$ ammonium ion initial concentration. The stirring time was fixed at 60 minutes. Reaction was carried out by stirring mixing sintering products with surfactant and $\mathrm{MB}, \mathrm{RhB}$ and ammonium ions at $600 \mathrm{rpm}$. Optimal conditions for the removal of both dyes \& ammonium ion were summarized in Table 1.

Based on the results obtained, $300^{\circ} \mathrm{C}$ was selected as a sintering temperature and ammonium ion was selected as contaminant for further studies. Morphology of the sintering products before and after adsorption of ammonium ions are given in Figure 2.

Table 1. Optimal conditions for MB, RhB and ammonium ion removal. Ethanol dose; $1 \mathrm{ml}$, adsorbent dose; $150 \mathrm{mg}$, initial conc. for MB \& RhB; $2.5 \mu \mathrm{g} / \mathrm{ml}$, ammonium ion; $1 \mu \mathrm{g} / \mathrm{ml}$, stirring time; $60 \mathrm{~min}$.

\begin{tabular}{|c|c|c|c|}
\hline \multirow{2}{*}{ Sintering temperature $\left({ }^{\circ} \mathrm{C}\right)$} & \multicolumn{3}{|c|}{ Removal efficiency (\%) } \\
\hline & MB & RhB & Ammonium ion \\
\hline 200 & 101.4 & 60.1 & 18 \\
\hline 300 & 97.1 & 75.7 & 52 \\
\hline
\end{tabular}




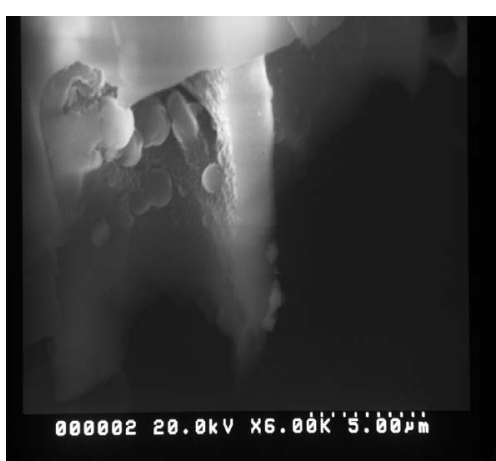

(a)

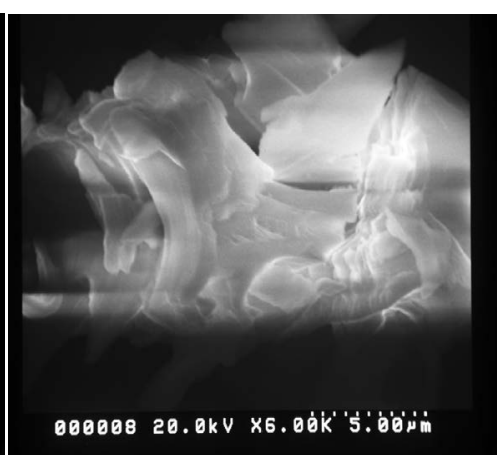

(b)

Figure 2. SEM image of carbon powder before (a) and after (b) ammonium ion adsorption.

\subsection{Effect of Adsorbent Amount on Ammonium Ions Removal}

Effect of the adsorbent amount on the ammonium ion removal efficiency was examined. Results are shown in Figure 3.

Removal efficacy was increased when the adsorbent amount was increased till became constant at $150 \mathrm{mg}$ and higher. The reason could be attributed to the surface area saturation capacity; therefore $150 \mathrm{mg}$ was selected for further studies.

\subsection{Effect of Stirring Time}

The effect of stirring time under optimal conditions was investigated as shown in Figure 4. Results show that increasing in removal efficiency was observed until $30 \mathrm{~min}$. Under the mentioned conditions, maximum removal efficiency obtained was $41 \%$. Therefore 30 min was selected as the optimum stirring time and used for further investigation.

\subsection{Effect of Sintering Temperature}

The effect of sintering temperature under optimal conditions was carried out at different temperatures $\left(100^{\circ} \mathrm{C}\right.$, $200^{\circ} \mathrm{C}, 300^{\circ} \mathrm{C}, 350^{\circ} \mathrm{C}$, at $400^{\circ} \mathrm{C}$ ) as shown in Figure 5 . Increasing in the removal efficiency was noticed up to $300^{\circ} \mathrm{C}$; however at higher temperature the removal efficiency was decreased. It is believed that the surface area of carbon powder was the largest at $300^{\circ} \mathrm{C}$. Based on the experimental data obtained, $300^{\circ} \mathrm{C}$ was selected to perform further studies.

\subsection{Effect of Sintering Time}

The effect of sintering time was tested under different time (30, 60, 90, 120, $180 \mathrm{~min})$. Results are summarized in Figure 6. Best result obtained when 60 min sintering time was applied. Maximum removal efficiency obtained is $52 \%$, which means that the adsorption process was spontaneous at low temperature range. Based on this result, 60 min sintering time was selected for further studies.

Under this experimental condition, 52\% removal efficiency was achieved.

\subsection{Effect of $\mathrm{pH}$}

Optimal condition effect of $\mathrm{pH}$ was determined under the selected other optimal conditions. Selected $\mathrm{pH}$ values and the removal efficiency obtained are shown in Figure 7. Adjustment of $\mathrm{pH}$ was carried out by using $\mathrm{H}_{2} \mathrm{SO}_{4}$ and/or $\mathrm{NaOH}$.

Maximum adsorption was occurred when the $\mathrm{pH}$ was near neutral $\mathrm{pH}$ between 6 and 7 . High $\mathrm{pH}$ shows that adsorption capability was decreased. This is contradictory to the trends noticed for the adsorption of ammonium ions by zeolites synthesized from fly ash and by coconuts shell activated carbon treated at $800^{\circ} \mathrm{C}$ [5] [35]. This could be attributed to the competition between negative and positive ions as well as the addition of surfactant (ethanol) into the solution. 


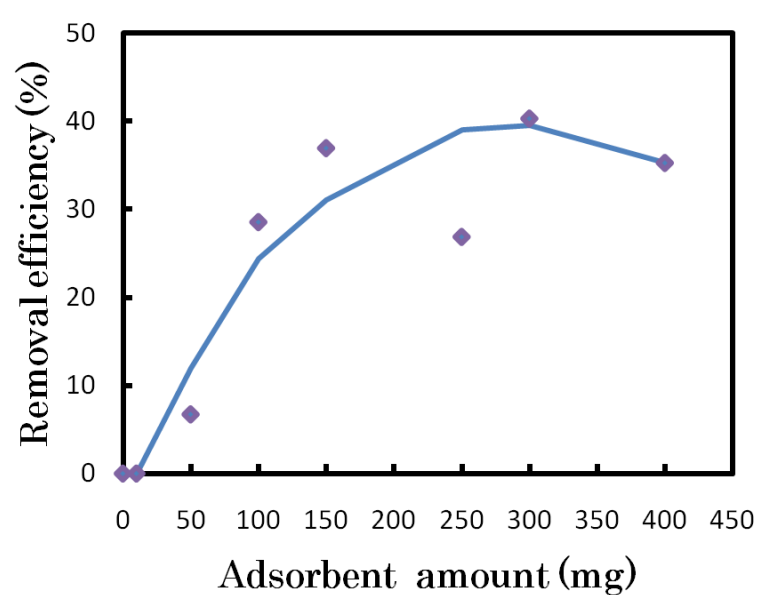

Figure 3. Effect of adsorbent amount on the removal efficiency of ammonium. Ammonium solution: $1 \mu \mathrm{g} / \mathrm{ml}$, ethanol: $1 \mathrm{ml}$, stirring time: $60 \mathrm{~min}, \mathrm{pH}: 6.2$, sintering temperature \& sintering time: $300^{\circ} \mathrm{C} \& 120 \mathrm{~min}$.

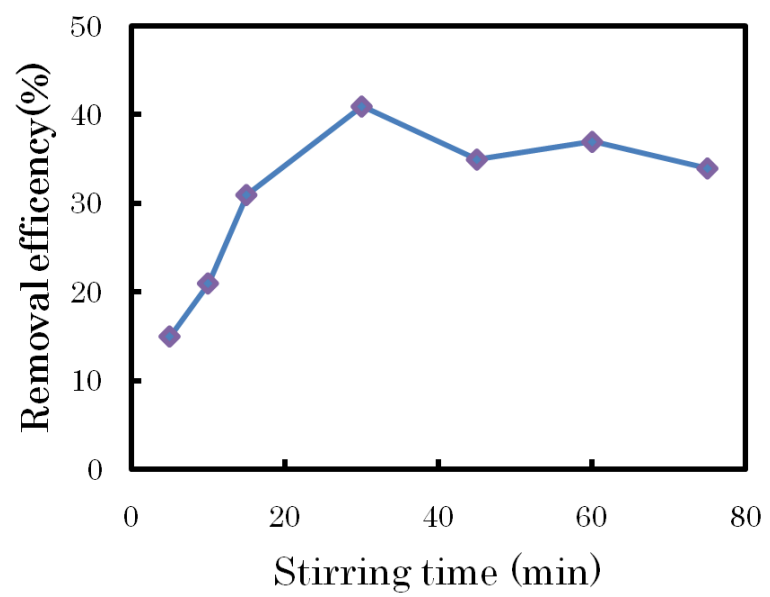

Figure 4. Effect of stirring time on the removal efficiency of ammonium ion. Ammonium solution: $1 \mu \mathrm{g} / \mathrm{ml}$, ethanol: $1 \mathrm{ml}$, adsorbent amount: $150 \mathrm{mg}, \mathrm{pH}$ : 6.2, sintering temperature \& sintering time: $300^{\circ} \mathrm{C} \& 120 \mathrm{~min}$.

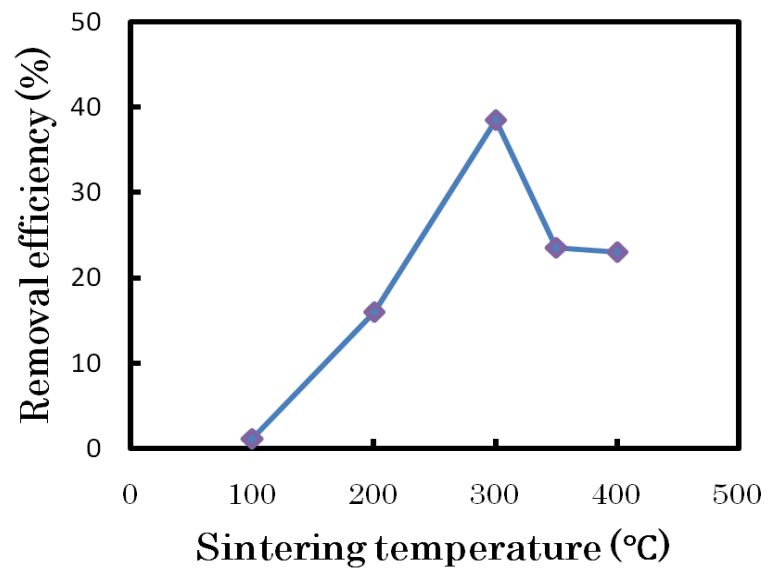

Figure 5. Effect of sintering temperature on the removal efficiency of ammonium ion. Ammonium solution: $1 \mu \mathrm{g} / \mathrm{ml}$, ethanol: $1 \mathrm{ml}$, stirring time: $60 \mathrm{~min}, \mathrm{pH}: 6.2$, adsorbent amount: $150 \mathrm{mg}$, sintering time: $300^{\circ} \mathrm{C} \& 120 \mathrm{~min}$. 


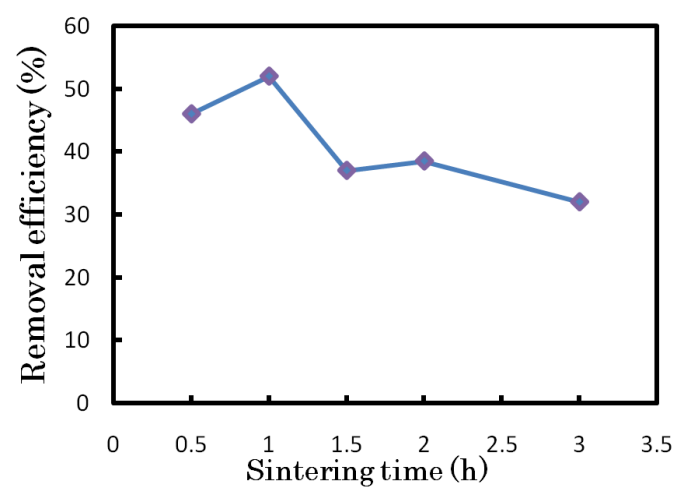

Figure 6. Effect of sintering time on the removal efficiency of ammonium ion. Ammonium solution: $1 \mu \mathrm{g} / \mathrm{ml}$, ethanol: $1 \mathrm{ml}$, stirring time: $60 \mathrm{~min}, \mathrm{pH}$ : 6.2 , sintering time: $300^{\circ} \mathrm{C}$ sintering product: $150 \mathrm{mg}$.

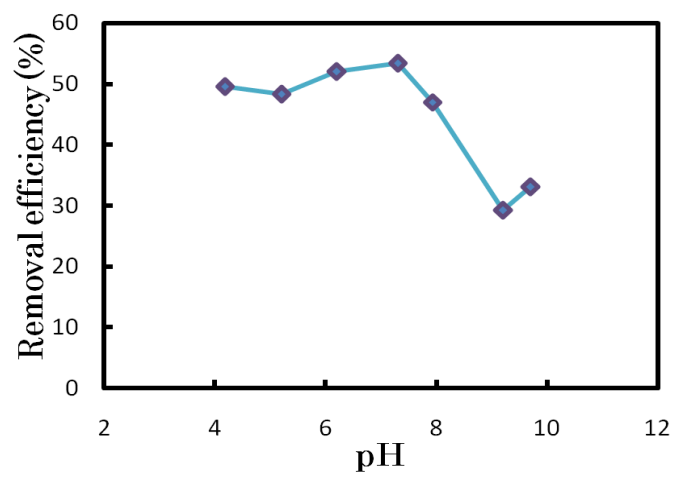

Figure 7. Effect of $\mathrm{pH}$ on the removal efficiency of ammonium ion. Ammonium solution: $1 \mu \mathrm{g} / \mathrm{ml}$, ethanol: $1 \mathrm{ml}$, stirring time: $60 \mathrm{~min}$, adsorbent amount: $150 \mathrm{mg}$, sintering temperature \& sintering time: $300^{\circ} \mathrm{C} \& 60 \mathrm{~min}$.

\subsection{Effect of Solution Temperature}

The influence of the solution temperature was evaluated under the same optimal conditions mentioned previously. Evaluation was carried out under constant temperatures; hot stirrer was used to ensure homogenous mixing. Results are shown in Figure 8, for each adsorption temperature. High removal efficiency was obtained when the solution temperature was fixed at $15^{\circ} \mathrm{C}(288 \mathrm{~K})$ suggesting that ion exchange capacity was maximum at lower temperature. Generally in chemical reactions, increasing the temperature leads to increase the reaction rates, however in this work chemical effect was negligible showing that only physical adsorption was occurred at lower temperature. Same pattern was observed when adsorption was carried out by using coconut shell [33]. This phenomenon could be attributed to the tendency of ammonium ion to desorb from the solid adsorbent to the bulk solution phase when temperature increases. Moreover, increasing the temperature will increase the rate of solute movement in the bulk solution and decrease the retarding forces acting on the adsorbate ions [33] [34].

\subsection{Van't Hoff Plot \& Adsorption Thermodynamics}

Thermodynamic energy parameters such as; change in the Gibbs free energy $(\Delta G)$, enthalpy $(\Delta H)$, and entropy $(\Delta S)$ were calculated by using the following equations:

$$
\begin{gathered}
K_{C}=\frac{C_{A}}{C_{S}} \\
\Delta G=-R T \ln K_{C} \\
\ln K_{C}=\frac{\Delta S}{R}-\frac{\Delta H}{R T}
\end{gathered}
$$


where $K_{C}$ is the equilibrium constant; $C_{A}$ is the concentration amount of ammonium ion adsorbed on the adsorbent from the solution at equilibrium (mg/l), $C_{S}$ is the equilibrium concentration of ammonium ions in aqueous solution (mg/l), the $\Delta S$ and $\Delta H$ were calculated from the slope and intercept of the Van't Hoff plot of 1/T against $\ln K_{C}$ as shown in Figure 9.

Thermodynamic analysis of ammonium ions adsorbed onto the sintering products made from cocoanuts husk wastes were tabulated in Table 2, under the same conditions applied in Figure 8.

In this study negative values were observed for the Gibbs free energy which indicates the degree of spontaneity of the adsorption process. The obtained values were ranged between $-4.4 \sim-3.9 \mathrm{~kJ} / \mathrm{mol}$ indicating that physical and spontaneous adsorption was occurred.

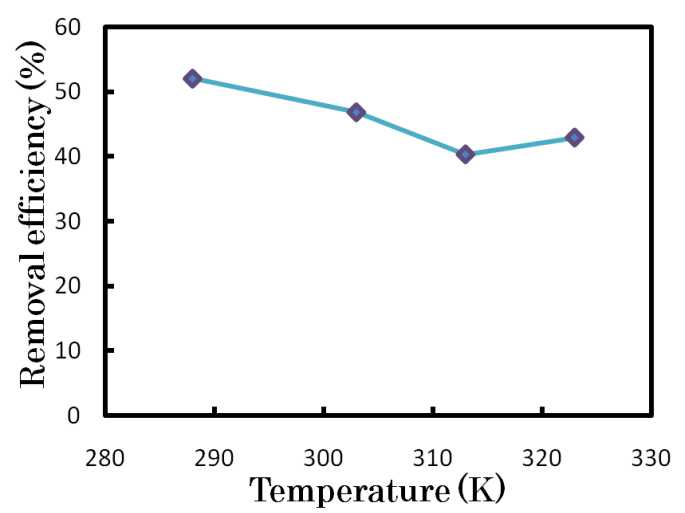

Figure 8. Effect of solution temperature on the removal efficiency of ammonium ion. Ammonium solution: $1 \mu \mathrm{g} / \mathrm{ml}$, ethanol: $1 \mathrm{ml}$, stirring time: $60 \mathrm{~min}, \mathrm{pH}: 6.2$, sintering temperature \& sintering time: $300^{\circ} \mathrm{C} \& 120 \mathrm{~min}$, adsorbent amount: $150 \mathrm{mg}$.

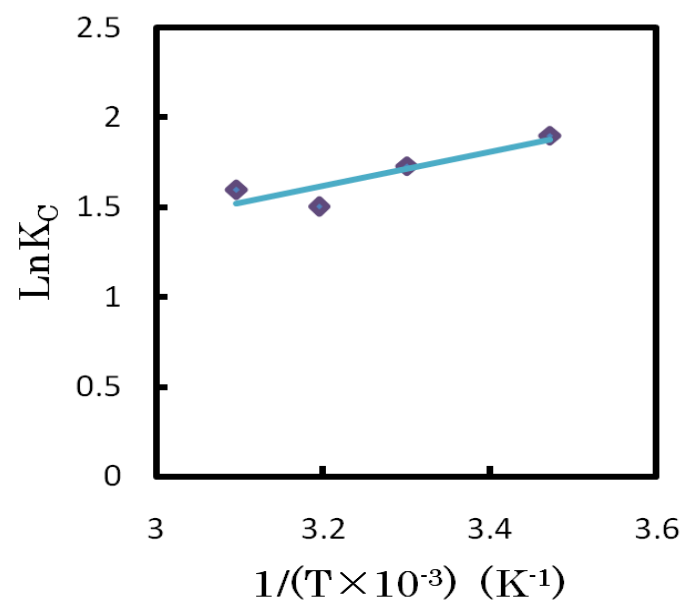

Figure 9. Van’t Hoff plot for the adsorption of ammonium ions onto sintering products made from coconuts husk wastes.

Table 2. Thermodynamic analysis of ammonium ion adsorbed onto carbon powder made from coconuts husk.

\begin{tabular}{|c|c|c|c|c|}
\hline Temperature (K) & Equ. cons $\left(K_{C}\right)$ & $\Delta G(\mathrm{~kJ} / \mathrm{mol})$ & $\Delta H(\mathrm{~kJ} / \mathrm{mol})$ & $\Delta S(\mathrm{~kJ} / \mathrm{mol})$ \\
\hline 288 & 6.67 & -4.421 & \multirow{4}{*}{-2.4} & \multirow{4}{*}{-11.8} \\
\hline 303 & 5.63 & -4.353 & & \\
\hline 313 & 4.49 & -3.909 & & \\
\hline 323 & 4.93 & -4.283 & & \\
\hline
\end{tabular}


In similar study where coconut shell-activated carbon was used this value ranged between $-2.1 \sim-1.5 \mathrm{~kJ} / \mathrm{mol}$ [35]. In general if Gibbs free energy $(\Delta H)$ ranged between $-20 \sim 0 \mathrm{~kJ} / \mathrm{mol}$, that is clear indication that adsorption process occurs physically [36]. Enthalpy $(\Delta H)$ and entropy $(\Delta S)$ show negative values also. In this study values of $\Delta H \& \Delta S$ were $-2.4 \&-11.8 \mathrm{~kJ} / \mathrm{mol}$ respectively. This interoperate why at low temperature high removal efficiency was obtained (refer to Figure 8). Since the effect of chemical adsorption is negligible and $\Delta S$ $\& \Delta H$ are negative, the relative magnitudes of $\Delta S$ and $\Delta H$ determine if the reaction is spontaneous at low temperatures and make the reaction more favorable due to exothermicity.

\section{Conclusion}

In Malaysia and other tropical countries, huge amounts of coconuts wastes are being produced every day. Utilizing these wastes instead of dumping could help environmental restoration and save dumping areas for other productive activates. Complete removal was achieved for the removal of Methylene Blue, $76 \%$ removal for Rhodamine B, whereas removal of ammonium ion reached around $52 \%$ when $300^{\circ} \mathrm{C}$ was applied as a sintering temperature for the wastes produced from coconuts husk.

\section{Acknowledgements}

This work was partly supported by TATI University College (Grant: 9001-2014), Malaysia, Part of the experiments were done in Mie University. Any opinions, findings, conclusions, or recommendations expressed in this paper are those of the authors and do not necessarily reflect the view of the supporting organizations.

\section{References}

[1] Erdem, E., Çölgeçen, G. and Donat, R. (2005) The Removal of Textile Dyes by Diatomite Earth. Journal of Colloid and Interface Science, 282, 314-319. http://dx.doi.org/10.1016/j.jcis.2004.08.166

[2] Hameed, B.H. (2009) Spent Tea Leaves: A New Non-Conventional and Low-Cost Adsorbent for Removal of Basic Dye from Aqueous Solutions. Journal of Hazardous Materials, 161, 753-759. http://dx.doi.org/10.1016/j.jhazmat.2008.04.019

[3] Pinheiro, H.M., Touraud, E. and Thomas, O. (2004) Aromatic Amines from Azo Dye Reduction: Status Review with Emphasis on Direct UV Spectrophotometric Detection in Textile Industry Wastewaters. Dyes and Pigments, 61, 121139. http://dx.doi.org/10.1016/j.dyepig.2003.10.009

[4] Babu, B.R., Parande, A.K., Raghu, S. and Prem Kumar, T. (2007) Cotton Textile Processing: Waste Generation and Effluent Treatment. Journal of Cotton Science, 11, 141-153.

[5] Wu, D., Zhang, B., Li, C., Zhang, Z. and Kong, H. (2006) Simultaneous Removal of Ammonium and Phosphate by Zeolite Synthesized from Fly Ash as Influenced by Salt Treatment. Journal of Colloid and Interface Science, 304, 300306. http://dx.doi.org/10.1016/j.jcis.2006.09.011

[6] Butt, M.T., Arif, F., Shafique, T. and Imtiaz, N. (2005) Spectrophotometric Estimation of Colour in Textile Dyeing Wastewater. Journal of the Chemical Society of Pakistan, 27, 627-630.

[7] Wu, J.S., Liu, C.H., Chu, K.H. and Suen, S.Y. (2008) Removal of Cationic Dye Methyl Violet 2B from Water by Cation Exchange Membranes. Journal of Membrane Science, 309, 239-245. http://dx.doi.org/10.1016/j.memsci.2007.10.035

[8] Fan, L., Zhou, Y., Yang, W., Chen, G. and Yang, F. (2008) Electrochemical Degradation of Aqueous Solution of Amaranth Azo Dye on ACF under Potentiostatic Model. Dyes Pigments, 76, 440-446. http://dx.doi.org/10.1016/j.dyepig.2006.09.013

[9] Banerjee, P., Dasgupta, S. and De, S. (2007) Removal of Dye from Aqueous Solution Using a Combination of Advanced Oxidation Process and Nanofiltration. Journal of Hazardous Materials, 140, 95-103. http://dx.doi.org/10.1016/j.jhazmat.2006.06.075

[10] Mahmoud, A.S., Brooks, M.S. and Ghaly, A.E. (2007) Decolorization of Remazol Brilliant Blue Dye Effluent by Advanced Photo Oxidation Process $\left(\mathrm{H}_{2} \mathrm{O}_{2} / \mathrm{UV}\right.$ System). American Journal of Applied Sciences, 4, 1054-1062. http://dx.doi.org/10.3844/ajassp.2007.1054.1062

[11] Fathima, N.N., Aravindhan, R., Rao, J.R. and Nair, B.U. (2008) Dye House Wastewater Treatment through Advanced Oxidation Process Using Cu-Exchanged Y Zeolite: A Heterogeneous Catalytic Approach. Chemosphere, 70, 11461151. http://dx.doi.org/10.1016/j.chemosphere.2007.07.033

[12] Lodha, B. and Chaudhari, S. (2007) Optimization of Fenton-Biological Treatment Scheme for the Treatment of Aqueous 
Dye Solutions. Journal of Hazardous Materials, 148, 459-466.

http://dx.doi.org/10.1016/j.jhazmat.2007.02.061

[13] Garcia-Montano, J., Perez-Estrada, L., Oller, I., Maldonado, M.I., Torrades, F. and Peral, J. (2008) Pilot Plant Scale Reactive Dyes Degradation by Solar Photo-Fenton and Biological Processes. Journal of Photochemistry and Photobiology A: Chemistry, 195, 205-214. http://dx.doi.org/10.1016/j.jphotochem.2007.10.004

[14] Wahyuningsih, S., Purnawan, C., Saraswati, T.E., Pramono, E., Ramelan, A.H., Pramono, S. and Wisnugroho, A. (2014) Visible Light Photoelectrocatalytic Degradation of Rhodamine B Using $\mathrm{Ti}^{-} \mathrm{TiO}_{2}-\mathrm{NiO}$ Photoanode. Journal of Environmental Protection, 5, 1630-1640. http://dx.doi.org/10.4236/jep.2014.517154

[15] Kadokawa, J., Izawa, H., Ohta, T., Wakizono, S. and Yamamoto, K. (2011) Photo-Induced Reduction Reaction of Methylene Blue in an Ionic Liquid. International Journal of Organic Chemistry, 1, 158-161. http://dx.doi.org/10.4236/ijoc.2011.14023

[16] Re, R., Liu, D., Li, K., Sun, J. and Zhang, C. (2011) Adsorption of Quaternary Ammonium Compounds onto Activated Sludge. Journal of Water Resource and Protection, 3, 105-113. http://dx.doi.org/10.4236/jwarp.2011.32012

[17] Iqbal, J., Kim, H.-J., Yang, J.-S., Baek, K. and Yang, J.-W. (2007) Removal of Arsenic from Groundwater by MicellarEnhanced Ultrafiltration (MEUF). Chemosphere, 66, 970-976. http://dx.doi.org/10.1016/j.chemosphere.2006.06.005

[18] Allen, S.J., Mckay, G. and Porter, J.F. (2004) Adsorption Isotherm Models for Basic Dye Adsorption by Peat in Single and Binary Component Systems. Journal of Colloid and Interface Science, 280, 322-333. http://dx.doi.org/10.1016/j.jcis.2004.08.078

[19] Ahsan, S., Kaneco, S., Ohta, K., Mizuno, T. and Kani, K. (2001) Use of Some Natural and Waste Materials for Waste Water Treatment. Water Research, 35, 3738-3742. http://dx.doi.org/10.1016/S0043-1354(01)00047-1

[20] Katsumata, H., Kaneco, S., Inomata, K., Itoh, K., Funasaka, K., Masuyama, K., Suzuki, T. and Ohta, K. (2003) Removal of Heavy Metals in Rinsing Wastewater from Plating Factory by Adsorption with Economical Viable Materials. Journal of Environmental Management, 69, 187-191. http://dx.doi.org/10.1016/S0301-4797(03)00145-2

[21] Hameed, B.H. (2009) Evaluation of Papaya Seeds as a Novel Non-Conventional Low-Cost Adsorbent for Removal of Methylene Blue. Journal of Hazardous Materials, 162, 939-944. http://dx.doi.org/10.1016/j.jhazmat.2008.05.120

[22] Han, B., Runnells, T., Zimbron, J. and Wickramasinghe, R. (2002) Arsenic Removal from Drinking Water by Flocculation and Microfiltration. Desalination, 145, 293-298. http://dx.doi.org/10.1016/S0011-9164(02)00425-3

[23] Johnson, B.B. (1990) Effect of pH, Temperature and Concentration on the Adsorption of Cadmium on Goethite. Environmental Science and Technology, 24, 112-118. http://dx.doi.org/10.1021/es00071a014

[24] Wu, Z., Gu, Z., Wang, X., Evans, L. and Guo, H. (2003) Effects of Organic Acids on Adsorption of Lead onto Montmorillonite, Goethite and Humic Acid. Environmental Pollution, 121, 469-475. http://dx.doi.org/10.1016/S0269-7491(02)00272-5

[25] Selvi, K., Pattabhi, S. and Kadirvelu, K. (2001) Removal of Cr(VI) from Aqueous Solution by Adsorption onto Activated Carbon. Bioresource Technology, 80, 87-89.

[26] Shekinah, P., Kadirvelu, K., Kanmani, P., Senthilkumar, P. and Subburam, V. (2002) Adsorption of Lead(II) from Aqueous Solution by Activated Carbon Prepared from Eichhornia. Wiley Online Library, Hoboken.

[27] Zhang, F.S., Nriagu, J.O. and Itoh, H. (2005) Mercury Removal from Water Using Activated Carbons Derived from Organic Sewage Sludge. Water Research, 39, 389-395. http://dx.doi.org/10.1016/j.watres.2004.09.027

[28] Yu, L. and Zhong, Q. (2006) Preparation of Adsorbents Made from Sewage Sludges for Adsorption of Organic Materials from Wastewater. Journal of Hazardous Materials, 137, 359-366. http://dx.doi.org/10.1016/j.jhazmat.2006.02.007

[29] Gihring, T.M. and Banfield, J.F. (2001) Arsenite Oxidation and Arsenate Respiration by a New Thermus Isolate. FEMS Microbiology Letters, 204, 335-340. http://dx.doi.org/10.1111/j.1574-6968.2001.tb10907.x

[30] Mohan, D. and Pittman, C.U. (2007) Arsenic Removal from Water/Wastewater Using Adsorbents-A Critical Review. Journal of Hazardous Materials, 142, 1-53. http://dx.doi.org/10.1016/j.jhazmat.2007.01.006

[31] Lorenzen, L., van Deventer, J.S.J. and Landi, W.M. (1995) Factors Affecting the Mechanism of the Adsorption of Arsenic Species on Activated Carbon. Minerals Engineering, 8, 557-569. http://dx.doi.org/10.1016/0892-6875(95)00017-K

[32] Iberhan, L. and Wiśniewski, M. (2002) Extraction of Arsenic(III) and Arsenic(V) with Cyanex 925, Cyanex 301 and Their Mixtures. Hydrometallurgy, 63, 23-30. http://dx.doi.org/10.1016/S0304-386X(01)00198-0

[33] Dabwan Ahmed, H.A., Daizo, I., Kaneco, S., Senmatsu, I., Nakahama, K., Katsuma, H., Suzuki, T. and Ohta, K. (2008) Water Purification with Sintered Porous Materials Fabricated at $400^{\circ} \mathrm{C}$ from Sea Bottom Sediments. Journal of Environmental Sciences, 20, 172-176. http://dx.doi.org/10.1016/S1001-0742(08)60027-3

[34] Boopathy, R., Karthikeyan, S., Mandal, A.B. and Sekaran, G. (2013) Adsorption of Ammonium Ion by Coconut ShellActivated Carbon from Aqueous Solution: Kinetic, Isotherm, and Thermodynamic Studies. Environmental Science and 
Pollution Research, 20, 533-542. http://dx.doi.org/10.1007/s11356-012-0911-3

[35] Karadag, D., Koc, Y., Turan, M. and Armagan, B. (2006) Removal of Ammonium Ion from Aqueous Solution Using Natural Turkish Clinoptilolit. Journal of Hazardous Materials, 136, 604-609. http://dx.doi.org/10.1016/j.jhazmat.2005.12.042

[36] Ugurlu, M., Gurses, A. and Acikyildiz, M. (2008) Comparison of Textile Dyeing Effluent Adsorption on Commercial Activated Carbon and Activated Carbon Prepared from Olive Stone by $\mathrm{ZnCl}_{2}$ Activation. Microporous and Mesoporous Materials, 111, 228-235. http://dx.doi.org/10.1016/j.micromeso.2007.07.034 
Scientific Research Publishing (SCIRP) is one of the largest Open Access journal publishers. It is currently publishing more than 200 open access, online, peer-reviewed journals covering a wide range of academic disciplines. SCIRP serves the worldwide academic communities and contributes to the progress and application of science with its publication.

Other selected journals from SCIRP are listed as below. Submit your manuscript to us via either submit@scirp.org or Online Submission Portal.
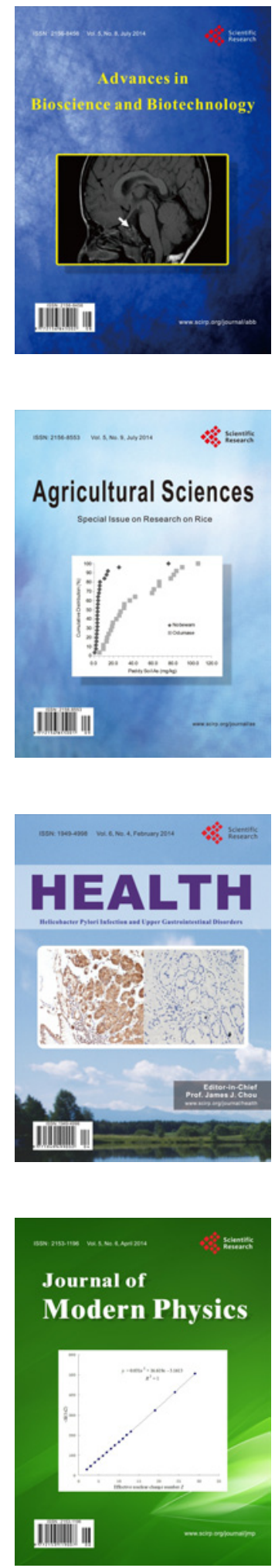
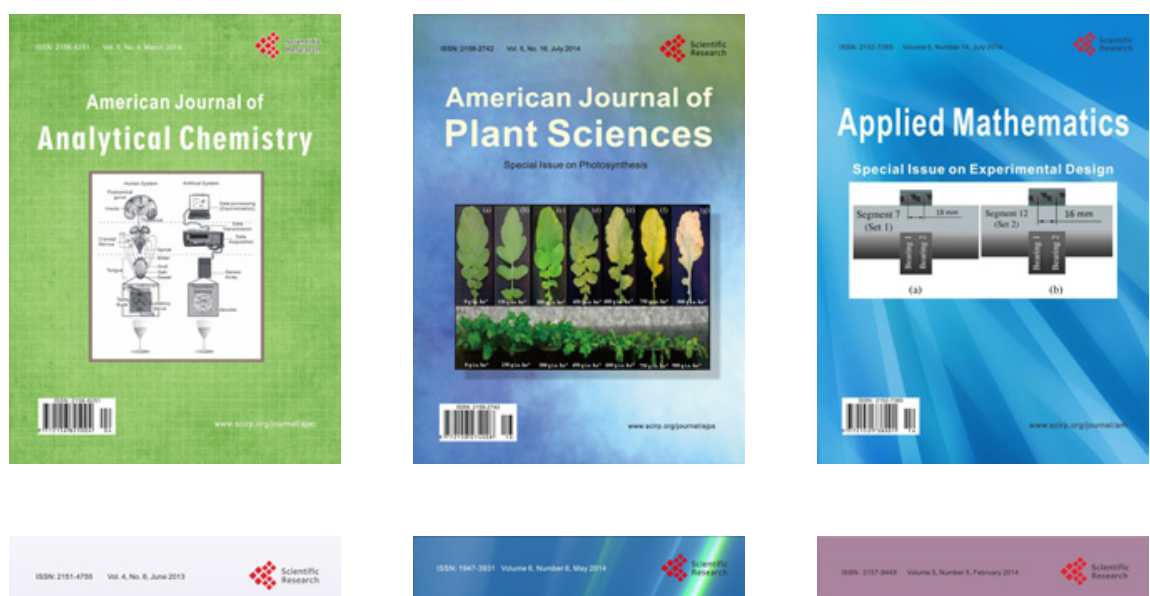

Creative Education
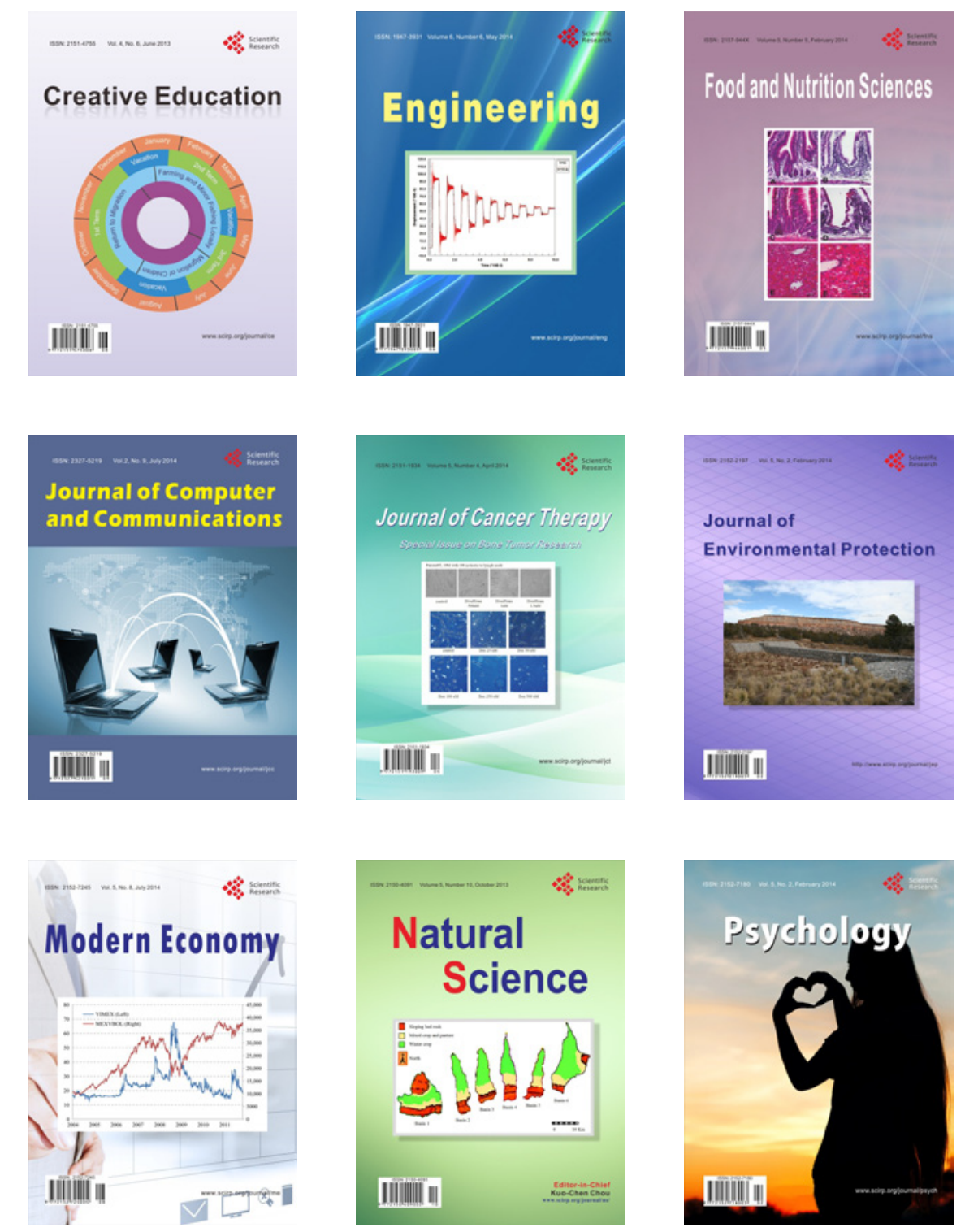